JUSTYNA ŁUKASZEWSKA-HABERKOWA* - KRAKÓW

\title{
DZIEJE PARAFII W ODROWĄŻU PODHALAŃSKIM W ŚWIETLE KRONIKI PARAFIALNEJ (1844)
}

Dziewiętnastowieczne dzieje parafii w Odrowążu i należących do niej wsi: Załucznego, Działu i Pieniążkowic, stanowią interesujący przykład samowoli mieszkańców, którzy postanowili własnoręcznie założyć wspólnotę i z uporem forsowali swe przekonanie o konieczności zbudowania kościoła w wyznaczonym przez siebie miejscu.

Dzieje samej parafii w Odrowążu sięgają czasów stosunkowo dawnych - początków wieku XVII. Od XVI w. rozpoczął się proces osadniczy na terenach południowych Rzeczypospolitej. W związku z tym na początku XVII wieku, staraniem Zofii Pieniążkowej z Bogusławic (de domo Sierakowskiej), oprócz dawniejszej, w Ludźmierzu, powstała parafia pod wezwaniem Trójcy Swiętej w Czarnym Dunajcu. Wśród innych należały do niej wsie: Czarny Dunajec, Chochołów, Załuczne, Podczerwone, Odrowąż, Dział, Pieniążkowice, Długopole oraz Wróblówka. Kolejne lata oraz powstanie na terenach sąsiadujących parafii luterańskiej ${ }^{1}$, przyczyniły się do tego, że kościołów nie budowano, a nowych parafii powstało zaledwie kilka.

Po roku 1772 zaborcy zdecydowali, że obszary diecezji krakowskiej, w skład której wchodziły omawiane ziemie (jako dekanat nowotarski), będą należały do Austrii ${ }^{2}$. Kolejne działania cesarza Józefa II zostały uznane przez papieża Piusa VI. Decyzją cesarza, dotychczasowa diecezja krakowska została podzielona na diecezję krakowską i tarnowską. W dalszej kolejności, na przełomie XVIII i XIX w. rozpoczął się proces odłączania się i usamodzielniania dotychczasowych filii,

* Justyna Łukaszewska-Haberkowa - dr neolatynistyki, adiunkt w Wyższej Szkole Filozoficzno-Pedagogicznej Ignatianum w Krakowie

${ }^{1}$ Ziemie te poddano przymusowej ewangelicyzacji. W pierwszej ćwierci XVII wieku Orawa znalazła się w jurysdykcji luterańskiej.

${ }^{2}$ Przygotowując rys historyczny korzystałam przede wszystkim z opracowania dziejów okolicy K. Szymusiaka-Nowakowskiego, Zapomniane Podhale. Czterysta lat wsi: Dział, Odrowąż, Pieniażkowice, Załuczne, Kraków 2004. Tam również znajduje się pełna bibliografia prac o omawianych terenach (s. 297-307). 
które istniały przy większych parafiach. Do takich należały kościoły filialne Czarnego Dunajca ${ }^{3}$.

Najpierw, w roku 1817, odłączyła się wspólnota z Chochołowa (kościół pod wezwaniem św. Jacka), choć wcześniej, bo od roku 1813, starania o utworzenie nowej parafii rozpoczęli mieszkańcy gminy Pieniążkowice. Dwukrotnie wysyłane petycje, którym towarzyszyły stosowne dokumenty państwowe oraz pozwolenie monarchy, odniosły wreszcie skutek. W roku 1818 przystąpiono do budowy kościoła pod wezwaniem św. Andrzeja.

Zgoda wyrażona przez metropolitę łacińskiego, który wówczas miał siedzibę we Lwowie, zawierała jednak pewne warunki. Po pierwsze na kościół powinno przypadać przynajmniej tysiąc wiernych, a obok świątyni powinny stanąć inne budynki: wikarówka oraz organistówka z osobnym pomieszczeniem dla kościelnego.

W tym samym czasie w oddalonym od Pieniążkowic o 1,5 km Odrowążu, mieszkańcy przystąpili do ofensywy w sprawie lokalizacji nowego kościoła. Wspierali ich ludzie z Załucznego i z Działu. Przewaga Odrowąża była znaczna, gdyż w tym czasie liczył 835 mieszkańców (Pieniążkowice 648) ${ }^{4}$. Ponadto od XVII wieku we wsi funkcjonowała drewniana kaplica $\mathrm{z}$ dzwonnicą, w której odprawiano nabożeństwa.

Mieszkańcy Odrowąża, w imieniu swoim oraz Działu i Załucznego, wystąpili do C. K. Urzędu Obwodowego w Nowym Sączu o zgodę na postawienie kościoła filialnego oraz pozostałych budynków. W piśmie zaznaczono, że do budowy przyczynią się mieszkańcy Pieniążkowic - dostarczając stosowną ilość materiałów i robocizny. Wreszcie w 1819 roku zapadła decyzja Najwyższej Kancelarii Nadwornej, która wyrażała zgodę na utworzenie osobnej parafii w gminie Odrowąż. Do parafii miały należeć: Dział, Pieniążkowice, Odrowąż i Załuczne, dotąd podległe parafii w Czarnym Dunajcu. Jednocześnie wyrażono zgodę na budowę osobnego kościoła filialnego w Pieniążkowicach. W kolejnych ustaleniach sprecyzowano, iż do czasu wybudowania plebanii i osadzenia nowego proboszcza, nabożeństwa i msze święte będzie odprawiał prepozyt z Czarnego Dunajca ${ }^{5}$.

Tymczasem mieszkańcy Pieniążkowic uparcie bronili swoich wcześniejszych praw. Za wszelką cenę starali się kontynuować budowę kościoła i zabiegali o utworzenie odrębnej parafii. W tym celu wskazywali, że są lepiej przygotowani do budowy, poczynili znaczne nakłady finansowe oraz rozpoczęli prace. Swymi działaniami mieszkańcy Pieniążkowic chcieli wyprzedzić podjęte dopiero działania Odrowążan i w ten sposób wymusić zmianę decyzji odnośnie erygowania parafii.

I tak w roku 1818 zaczęto odprawiać nabożeństw w nowopowstałej kaplicy, a następnie również chrzcić dzieci. $Z$ kolei następnym posunięciem w roku 1820 było wyznaczenie miejsca pod cmentarz, na którym od razu rozpoczęto pochówek zmarłych. Kolejne działania (w tym przygotowanie inwentarza kościelnego) księ-

\footnotetext{
${ }^{3}$ Tamże, s. 5.

${ }^{4}$ Dla porównania: dzisiaj parafia w Odrowążu liczy ok. 1300 wiernych, z tego 700 z Odrowąża Podhalańskiego, a 600 z Załucznego, por. http://www.diecezja.pl/pl/parafie/599 (10.03.2011).

${ }^{5}$ Szymusiak-Nowakowski, Zapomniane Podhale, s. 6.
} 
dza proboszcza z Czarnego Dunajca i parafian z Pieniążkowic w dalszym ciągu zdawały się potwierdzać istnienie odrębnej parafii ${ }^{6}$.

Spór między wsiami ciągnął się pomimo dalszych interwencji ze strony administracji państwowej, które miały wymóc posłuszeństwo od opornych wiernych. Mieszkańcy Odrowąża ze swej strony nie ustępowali w staraniach o podporządkowanie parafian z Działu i Pieniążkowic. Ci zaś sabotowali budowę nowego kościoła $\mathrm{w}$ ten sposób, że uparcie odmawiali pomocy (nie dostarczyli obiecanych materiałów budowlanych i wsparcia siłą fizyczną). Pomimo tego, że mieszkańcy Pieniążkowic nie pomagali w pracach, Odrowążanie już w 1825 roku przystąpili do murowania kościoła. Niewątpliwie musiała na to wpłynąć decyzja właściciela dóbr - Sebastiana Stadnickiego ${ }^{7}$, który do tej pory wahał się co do lokalizacji nowej świątyni ${ }^{8}$.

Sebastian Stadnicki stał się właścicielem wsi w roku 1819, kiedy nabył je jako część dóbr narodowych sprzedawanych przez zaborców jako tzw. dobra kameralne. Hrabia zakupił tzw. Dominium Klikuszowa, do którego należały również Dział, Odrowąż, Pieniążkowice i Załuczne.

W tych latach powstało wiele aktów prawnych (Urzędu Obwodowego w Nowym Sączu, Najwyższej Kancelarii Nadwornej, oraz innych ${ }^{9}$ ), które miały utwierdzić decyzje o wydzieleniu z parafii czarnodunajeckiej czterech wsi: Działu, Pieniążkowic, Załucznego i Odrowąża oraz o utworzeniu tamże nowej, samodzielnej parafii. W związku z tym, że znalazł się właściciel majątku w konkretnej osobie Sebastiana Stadnickiego, Odrowążanie postanowili prawnie rozwiązać ciągnący się spór i wystosowali pismo do Najwyższej Kancelarii Nadwornej, w którym upominali się o obiecaną im pomoc i erygowanie kościoła.

Rozpoczętą budowę ukończono w roku 1825. Dopiero jesienią tego roku administracja państwowa zmusiła mieszkańców Załucznego, Działu i Pieniążkowic do pomocy przy pracach. Murowany kościół ulokowano na skrzyżowaniu dwóch najważniejszych dróg we wsi (prowadzących od Pieniążkowic do Załucznego oraz z dolnej części Odrowąża w stronę Beskidu). Po wspomnianej wyżej decyzji kolatora, Sebastiana Stadnickiego, prace udało się szybko i sprawnie ukończyć.

\footnotetext{
${ }^{6}$ Tamże, s. 8-9.

${ }^{7}$ Więcej o Sebastianie Stadnickim i jego rodzinie: Szymusiak-Nowakowski, Zapomniane Podhale, s. 100-101.

${ }^{8}$ Tamże, s. 11.

${ }^{9}$ Były to m.in. Zgoda C.K. Urzędu Obwodowego w Nowym Sączu na lokalizację i budowę kościoła w Odrowążu z dnia 21.11.1817 (L. 8851), Decyzja Generalnego Wikariatu w Starym Sączu o poparciu starań Odrowąża z dnia 21.09.1817 r., Potwierdzenie przez C.K. Urząd Cyrkularny w Nowym Targu decyzji o budowie kościoła w Odrowążu celem powstrzymania gminy Pieniążkowice do konkurowania w utworzeniu parafii z dnia 8.07.1818, Dekret Najwyższej Kancelarii Nadwornej z dnia 18.03.1819 (L. 8450), że Najjaśniejszy Cesarz zezwolił utworzyć parafię w gminie Odrowąż, Dekret Gubernium we Lwowie z dnia 23. 04. 1819 (L. 16175) potwierdzający zgodę cesarską, Zarządzenie C.K. Urzędu Obwodowego w Nowym Sączu z dnia 24.07.1819 (L. 3878) o wybudowaniu mieszkania dla proboszcza i opieki nad nim czterech gmin oraz Powiadomienie gmin Odrowąż, Dział, Pieniążkowice i Załuczne przez Państwo Nowotarskie z dnia 16.08.1819 o decyzjach władz wyższych w sprawie utworzenia parafii odrowąskiej.
} 
Wejście do kościoła prowadziło przez wieżę z zegarem. Po lewej stronie świątyni dobudowano odrębną kaplicę grobową dla rodziny Stadnickich, natomiast cały obszar przykościelny otoczono murem. Właściwie taki stan przedstawia on do dzisiaj. Obok kościoła znajduje się cmentarz i prowadząca nań brama.

Sama bryła świątyni stanowi jeden z typowych przykładów obowiązującego w ówczesnej architekturze, tzw. stylu józefińskiego. Raczej klasycystyczna z charakteru, ma kilka elementów nawiązujących do baroku: linię gzymsów i dachu, hełm na wieży oraz sygnaturkę ${ }^{10}$.

Rodzinę Stadnickich jako kolatorów upamiętnia kilka elementów kościoła. Przede wszystkim jednak jego wezwanie - św. Marii Magdaleny. Takie imię nosiła małżonka Sebastiana Stadnickiego de domo Czerny de Szwarcenberg. W ołtarzu głównym obok figur świętej Marii Magdaleny i świętego Sebastiana znajdują się także figury rzadziej spotykanych świętych: Leona i Hilarego, patronów dwóch synów kolatorów. Ołtarz główny jest najważniejszym dziełem znajdującym się w kościele. Zaprojektował go i wyrzeźbił, podobnie jak większość wyposażenia świątyni, Józef Kudłach z Szaflar. Był on snycerzem i rzeźbiarzem, a styl ołtarza nawiązuje do świątyni nowotarskiej, jako przykład tzw. „stolarskiego klasycyzmu”. Obrazy Marii Magdaleny i świętego Sebastiana, które znajdują się w ołtarzu, namalował Jan Kanty Wojnarowski ${ }^{11}$.

Uroczyste poświęcenie kościoła odbyło się dopiero 1 sierpnia 1832 roku. Dokonał go biskup Franciszek Pisztek, a towarzyszyli mu m.in. ks. Wojciech $\mathrm{Ku}-$ backi, dotychczasowy administrator parafii, proboszcz w Czarnym Dunajcu. On także pozostał opiekunem kościoła do 1838 roku. W tym czasie wybudowano plebanię i organistówkę z pozostałymi pomieszczeniami.

Dopiero 2 sierpnia 1839 roku, siedem lat po poświęceniu kościoła, przybył do Odrowąża pierwszy proboszcz. Był nim Jan Kanty Miśs ${ }^{12}$. Wkrótce zmarł kolator świątyni, właściciel Dominium Klikuszowa, Sebastian Stadnicki, który został pochowany w wybudowanej przez siebie kaplicy grobowej. Dziedzicem majątku (wsi Odrowąż, Dział, Pieniążkowice i Załuczne) i nowym kolatorem został syn Sebastiana, Hilary Stadnicki.

Nowo objęta prepozytura nie należała do prostych. Jan Kanty Miś, choć był raczej prostym księdzem, w ciągu swej bardzo długiej posługi, musiał nieustannie zmagać się z rozmaitymi trudnościami. Pierwsza dotyczyła sporu o wysokość należnej mu pensji - wyznaczonej wcześniej sumy nie chcieli zapłacić mieszkańcy wsi podlegających prepozyturze. Następnie proboszcz musiał wspierać nauczyciela w szkole, Wincentego Chlebowskiego, który pełnił także funkcję organisty

${ }^{10}$ T. Chrzanowski, M. Kornecki, Sztuka Ziemi Krakowskiej, Kraków 1982, s. 368-371, 505, $536,552$.

${ }^{11}$ Jan Kanty Wojnarowski z wykształcenia był architektem. Jako malarz mniej znany, jedynie ze szkiców i rysunków architektonicznych, które wykonywał z dużą sprawnością. Przyjmuje się, że należał do grona wedutystów, grupy malarzy, którzy w twórczości uwieczniali widoki i zabytki Małopolski.

${ }^{12}$ Jan Kanty Miś urodził się 24. 10. 1807 roku w Zembrzycach, zmarł 9.12.1898 w Odrowążu. Święcenia przyjął w roku 1833, następnie został wikarym w Czarnym Dunajcu (1833-1835), z kolei proboszczem w Klikuszowej (1835-1838) i proboszczem w Odrowążu (od 1839). 
kościelnego, ponieważ włościanie odmówili posyłania dzieci do szkoły. Wreszcie wśród innych trudności warto wspomnieć, że z powodu oporu, który stawiali mieszkańcy wsi, proboszcz oddał część ziemi plebańskiej pod ogródek szkolny. Naturalnie bez żadnego zadośćuczynienia ze strony wiernych. Podobne problemy dotyczyły miejsca pod nowy cmentarz.

Ponadto Jan Kanty Miś był wielkim przyjacielem rodziny Stadnickich. Ich zażyłość datowała się od lat 30. XIX wieku, gdy jako neoprezbiter, a następnie wikary w Czarnym Dunajcu, Miś pełnił funkcję administratora w Klikuszowej. W roku 1845 po przedwczesnej śmierci drugiego z kolei kolatora kościoła - Hilarego - starał się wesprzeć jego rodzinę (zwłaszcza małoletnią córkę właściciela, Leonę). Ponadto śmierć dotychczasowego dobrodzieja przyniosła ze sobą niekorzystną zmianę władzy: po śmierci dziedzica, jego funkcję pełnił plenipotent. Była to osoba wyjątkowo pazerna, znienawidzona przez miejscowych, którzy nazywali go „tyranem chłopów”.

Bracia Stadniccy wspierali księdza Misia również w walce politycznej. Jako zagorzały obrońca wolności i ojczyzny, wraz z organistą i nauczycielem w Odrowążu, Wincentym Chlebowskim, proboszcz regularnie agitował w sprawie odzyskania niepodległości, organizował oddziały powstańcze i pomagał działaczom politycznym.

Ksiądz Miś, jak można sądzić z zachowanych opisów, był człowiekiem pracowitym, myślącym i krewkim. Być może właśnie tym cechom zawdzięczał swoją długowieczność, ponieważ, rzecz niebywała nie tylko dzisiaj, w roku 1889 obchodził sekundację w Odrowążu. Ta uroczystość kościelna stanowi jedno z naj-rzadszych wydarzeń: jest to jubileusz pięćdziesięciolecia pełnienia obowiązków plebańskich w jednym miejscu. $Z$ tej okazji parafia w Odrowążu przeżyła prawdziwy najazd krewnych, parafian i przyjaciół księdza, a korzystając ze sposobności, pojawili się również księża dekanatu nowotarskiego urodzeni we wsi.

Wprawdzie jubileusz mógł sędziwego proboszcza skłonić do emerytury lub przynajmniej odpoczynku, jednak ruchliwy pleban w kolejnym dziesięcioleciu rozpoczął przebudowę kościoła w Pieniążkowicach. Po wielu latach od zatargu, który odbił się niemałym echem w okolicy, mieszkańcy tej wsi mieli osiągnąć swój cel: powiększyć kaplicę i poświęcić świątynię. Historia zatoczyła koło.

Jan Kanty Miś nie ukończył rozpoczętego dzieła - zmarł w grudniu 1898 roku i spoczął na odrowąskim cmentarzu. Pozostawił po sobie znakomicie funkcjonującą, ogromną parafię, ukończone inwestycje, szkoły, a przede wszystkim życzliwe wspomnienia wdzięcznych parafian.

Kronika parafialna kościoła w Odrowążu datuje się stosunkowo późno, bo dopiero na rok 1844. Pierwsza jej część, najbardziej interesująca, została zapisana po łacinie. Język, którym przedstawiono erygowanie kościoła, konflikt między Odrowążanami i mieszkańcami pozostałych wsi oraz pierwsze lata probostwa Jana Kantego Misia, jest bardzo prosty i raczej poprawny. Jednakże niektóre zdania zbudowane są niekonsekwentnie, co utrudnia ich zrozumienie oraz przetłumaczenie tekstu. Często pierwsza część zdań nie łączy się z pozostałą ich częścią, a kolejne frazy nie pozostają w logicznym związku. Znamienne dla epoki są bardzo rozbudowane zwroty tytularne rodziny Stadnickich oraz zamiłowanie, którym 
proboszcz darzył wszelkie nazwy instytucji. Można sądzić, że pierwszą, zasadniczą partię tekstu, napisał ksiądz Miś. Temu, jak się wydaje, należy przypisywać nieco emocjonalny charakter narracji ${ }^{13}$.

Początkowa część kroniki przedstawia położenie Odrowąża i stan przynależności. Wymieniono także ważniejsze dokumenty lokujące kościół ${ }^{14}$. Z kolei, jeśli można tak uznać, w drugim rozdziale, autor przypomina uroczystość poświęcenia świątyni oraz przytacza odpowiednie błogosławieństwo. W tym miejscu opisano również dokładnie sytuację religijną Kościoła i polityczną wsi: erygowano świątynię za pontyfikatu papieża Leona XII, pod władaniem Franciszka II. W kolejnych zdaniach autor wspomina wydarzenia lat minionych: Święte Przymierze zawarte przeciw Karbonariuszom oraz pokonanie i uwięzienie Napoleona na Wyspie św. Heleny.

Wspominano również pomniejsze wydarzenia, jak np. ogromną powódź, która nawiedziła Małopolskę i ziemie Królestwa Polskiego w roku 1813, po czym narracja powraca do kościoła w Odrowążu. Najpierw ponownie przypomniano akt poświęcenia świątyni oraz osoby jej kolatorów: Sebastiana i Marii Magdaleny de Szwarcenberg Szreniawa Stadnickich. Ks. Miś wymienia następnie wszystkie osoby, które przybyły na uroczystość, w tym wspomnianych wyżej, księdza Biskupa Grzegorza Tomasza Zieglera, prałata Ignacego Machajskiego oraz licznie zgromadzoną szlachtę. Wszystkie osoby otrzymały stosowne tytuły. W kolejnym akapicie autor nagle i zdawkowo urywa opis, po czym zwraca się do czytelników i następców z prośbą o modlitwę i pamięć. Wreszcie wymieniono osoby zgromadzone 22 lipca 1825 roku w domu parafialnym w Odrowążu.

Krótkie informacje odnoszą się do kolejnych wydarzeń związanych z budową kościoła, które wymieniłam we wcześniejszej części artykułu. Oto ks. Miś wspomina chęć i zapał wiernych, którzy koniecznie chcieli zobaczyć nowy kościół. Dodaje również, że ludzie ci dobrowolnie przyjęli na siebie ciężar trudów związanych z budową.

${ }^{13}$ Pod artykułem zamieściłam pełną wersję kroniki w języku łacińskim, natomiast w przypisach przetłumaczone fragmenty bez tekstu łacińskiego.

${ }^{14}$ „Wieś Odrowąż, (...) sięga do pierwszego kamienia milowego, składa się z dwudziestu tak zwanych Ról, zawiera 200 domów, razem z Wójtostwem. [Należała] niegdyś do sławnej rodziny Odrowążków, teraz zaś rodziny Bielańskich. Do tego Kościoła dołączone są, oprócz Odrowąża, wsie: Pieniążkowice, Dział i Załuczne, należące niegdyś (aż do roku 1819) do Skarbu Królewskiego we władztwie Nowotarskim. Po sprzedaniu tych wszystkich dóbr, przeszły z innymi [włościami] w sukcesję sławnego Sebastiana Stadnickiego ze Szreniawy. Teraz znajdują się pod Władaniem Klikuszowickim. Te cztery wioski należały do Kościoła Macierzystego w Czarnym Dunajcu- najpierw w roku 1819 na mocy Dekretu Najwyższej Kancelarii Dworskiej z dnia 23 Kwietnia, $\mathrm{Nr}$ 16175, po uzyskaniu pełnomocnictwa dla erygowania Nowego Kościoła, a po jej otrzymaniu - 22 Lipca 1825. W święto św. M. Magdaleny, która była patronką Wielmożnej Pani Czerny ze Schwarzenberga, żony Sebastiana Stadnickiego ze Szreniawy, w dowód wdzięczności także i Kościół otrzymał tejże Fundatorki Patronkę za swoją". 
Z kolei następny akapit odnosi się do czasów bliższych pisaniu kroniki, do roku 1832. Wówczas postawiono ołtarz główny, który wykonał wspominany wcześniej Józef Kudłach. Na uwagę zasługuje krótki opis jego elementów ${ }^{15}$.

Wreszcie w kolejnym rozdziale przedstawiono lata probostwa pierwszego prepozyta - Wojciecha Kubackiego. W kronice został on nazwany pierwszym proboszczem, co nie do końca odpowiada historii, gdyż pełnił funkcję administratora parafii. Według kroniki ksiądz Kubacki po wielu niesnaskach opuścił dotychczasową parafię w Czarnym Dunajcu i przeniósł się do Odrowąża. Autor wyraża nadzieję, że decyzja księdza Kubackiego spotka się ze zrozumieniem ze strony następców i czytelników. Proboszcz ten przejął urząd z rąk kolatora Stadnickiego. Starał się rozbudować i wzbogacić parafię, sprawiając jej nowe sprzęty i wyposażenie do świątyni, co skrupulatnie odnotowano w kronice. Nieco dłużej ks. Miś zatrzymał się nad sprowadzeniem i poświęceniem dzwonów kościelnych. Dokładnie wymienia uroczystości i dokumenty związane z tym wydarzeniem. Ostatnie zdania rozdziału wspominają dalsze działania proboszcza oraz okoliczności jego śmierci - następca pochował go w kościele ${ }^{16}$.

${ }^{15}$ „W roku bieżącym, to jest 1832, postawiony został przez Józefa Kudłacha włościanina z parafii Szaflary ze wsi Glejczarów, Większy Ołtarz, cały drewniany, [wykonany] wystarczająco i stosownie na wzór Ołtarza z Nowego Targu. Na środku tego ołtarza znajduje się wizerunek Świętej Marii Magdaleny namalowany przez sławnego malarza Pana Jana Kantego Wojnarowskiego z Akademii Krakowskiej, z funduszy Szanownej Pani Magdaleny ze Szreniawy Stadnickiej oraz dalszych Pana Sebastiana, które wystarczyły na budowę ołtarza, oprócz wizerunków w ołtarzu nic więcej malowanego w kościele nie ma. Pod wizerunkiem Świętej Marii Magdaleny znajduje się figura (obraz) Najświętszego Pana Jezusa, naturalnej wielkości człowieka, w otoczeniu stojących obok dwojga innych Świętych Marii, i Świętego Jana. [Rzeźby] te jakby, bardzo stosownie, otaczają rzeźbę z drewna.

Cała struktura Ołtarza składa się z dwóch kolumn, które u szczytu podtrzymują dwa Cherubiny. Na szczycie północnej kolumny znajduje się figura Świętego Antoniego, naprzeciwko której znajduje się figura Świętego Leona Papieża. Na wierzchołku kolumny południowej jest figura Świętego Józefa, przy boku którego postać Świętego Hilarego Biskupa. Obok ramy Obrazu Świętej Marii Magdaleny znajduje się bardzo wiele małych główek Serafinów o rzeźbionych twarzach, i dwa małe Cherubiny - poniżej. Wizerunku ołtarza znajduje się tabernakulum odpowiednio przeznaczone do przechowywania Najświętszego Sakramentu, zbudowane z wielką pobożnością i troską. Obok niego dwa klęczące Cherubiny, trzymające w dłoniach, wysoko ponad tabernakulum, dwa kandelabry. Tuż przy Zakrystii znajduje się ambona - którą wraz z Ołtarzem, jak wyżej zostało napisane, sprawił sam jeden tylko Pan Sebastian Stadnicki dziedzic i kolator, i oddał pod dozór pierwszego Proboszcza tego Kościoła, którym był Wielebny Wojciech Kubacki”.

16 „Pierwszy jako Proboszcz ten urząd otrzymał Najwielebniejszy Wojciech Kubacki. Wcześniej był on Proboszczem w Czarnym Dunajcu, [który opuścił] z powodu bardzo licznych nieprzyjemności, których tamże właśnie doznał w owym czasie od osoby znanej ze złej sławy: Kajetana Barona z Borowskich. Nie nam tu mówić o historii pozyskania przez niego dóbr w Czarnym Dunaj$\mathrm{cu}$, procesów, życia i działalności, lecz jeśli drodzy Następcy z ust całego ludu w tych okolicach Karpackich mieszkającego usłyszą [historię], przekazaną nawet po bardzo wielu latach od wydarzeń minionych, zadziwią się niezmiernie.

Ubolewać trzeba będzie, jeśli w Czarnym Dunajcu ani dla dalszej pamięci, napomnienia, zapisu, i nauki z dziejów nie pozostanie to zapisane w historii. Byłoby to bowiem dla Drogich Potomnych jakby [trucizna dla] pszczół zbierających miód z zatrutych kwiatów. Dlatego też rozumieją 
Bardziej interesujący rozdział kroniki kościoła w Odrowążu dotyczy Kaplicy Pieniążkowickiej. To stosunkowo krótki fragment, w którym autor najpierw przedstawił powody spisania dziejów tego miejsca. Z kolei omawia przyczyny konfliktu: nie są one dość jasne. Jak wynika z opisu, spór powstał w chwili, gdy wsie podzielono na przynależne do Odrowąża (Odrowąż i Załuczne) oraz pozostałe w Sołectwie Pieniążkowickim. Tam też miał stanąć kościół parafialny. Tymczasem Odrowążanie zakupili kawałek ziemi pod kościół. Przystąpili do budowy, ale zanim ukończyli prace, mieszkańcy Pieniążkowic wystawili swój własny: mały i drewniany kościół. Wyposażyli go sprzętami ze skasowanego klasztoru franciszkanów w Starym Sączu i poświęcili korzystając z posługi proboszcza w Czarnym Dunajcu. W tym samym czasie, co wiadomo z wcześniej przedstawionych dziejów parafii, powstawał kościół w Odrowążu. Autor krótko przedstawia sprawę konfliktu pisząc, że niesnaski i trudności ciągnęły się przez kolejne lata. Spór sięgał Sądu Kapitulnego, natomiast interesujące wydają się informacje uzupełniające. Według nich sołtys Pieniążkowic, Józef Waligórski, obiecywał, że swój majątek poświęci na rzecz budowy kościoła, a także zdobędzie dodatkowe fundusze od proboszcza w Czarnym Dunajcu. Po niespodziewanej śmierci sołtysa stało się jasne, iż rzecz nie dojdzie do skutku. Jak wspomina autor kroniki: „tak oto nadziei stał się koniec" ${ }^{17}$ oraz ,Zwycięzcami w procesie zostali mieszkańcy Odrowąża"18. Wprawdzie mieszkańcy Pieniążkowic nie mieli ku temu żadnych powodów, jednak wciąż żywili nadzieję na swój kościół. Jak zaznaczył autor temu należy przypisywać niechęć do świątyni w Odrowążu. Nienawiść między mieszkańcami wsi utrwaliła się jednak. Nawet działania proboszcza mające na celu pojednanie z pieniążkowickimi chłopami niewiele wniosły nowego: nie zgodzili się na to, by przenieść ruchomości i sprzęty z kaplicy w Pieniążkowicach. Z uporem odnawiają i pielęgnują to miejsce.

Wreszcie ostatnia część kroniki przedstawia osobę i dokonania drugiego proboszcza w Odrowążu, którego, jak zaznaczyłam wcześniej, zgodnie z literą prawa należy uznać za pierwszego jej prepozyta.

W pierwszym akapicie przedstawiono osobę Jana Kantego Misia: miejsce urodzenia, wykształcenie oraz pierwsze lata posługi kapłańskiej. Z kolei autor przechodzi do opisu nowej parafii, którą wymieniony ksiądz otrzymał w Odro-

drodzy Następcy rację i powód, dla którego ten proboszcz opuściwszy włości w Czarnym Dunajcu, przejął urząd w Odrowążu. Przejąwszy przeto dobra osobiście od Pana Sebastiana Stadnickiego, kolatora, dnia Lutowego 1832 roku, niniejszym został mianowany Proboszczem w Odrowążu. (...) Podobnie za rządów tego proboszcza przez Należących do wspólnoty Parafian zostały sprawione dwa dzwony, które wiszą w wieży. W dniu Pobłogosławienia przez Arcybiskupa Ołomuńskiego i roku, w dzień święty od słowa do słowa tak zostało napisane: (...) Za jego pobytu tutaj to godne jest wymienienia, że dzięki jego zapobiegliwości zostały zbudowane z kamieni obory, spichlerze i piwnica na zboże. Podobnie, dzięki jego staraniom u Wysokiej Władzy Państwowej został ustanowiony dodatek na stały dochód probostwa dla osoby Proboszcza w wysokości 205 florenów oraz sporządzono Inwentarz. Cóż, i jakże wiele mógłby jeszcze zdziałać w pokoju, lecz Kloto przerwała przędzioną nić jego życia, albowiem aż do 6 Lutego 1839 silną gorączką był trawiony i zmarł, i u wejścia od strony południowej, czyli od wejścia dla ludu, został pochowany w babieńcu".

${ }^{17}$ Et hinc spei factus finis.

${ }^{18}$ Hic victores processus Odrowazenses evasere. 
wążu: ,jedynie prawie cztery całkiem gołe ściany"19, jeśli nie liczyć elementów wyposażenia kościoła. Opisuje pokrótce mizerny stan gospodarstwa, które otrzymał po poprzedniku. Wreszcie przedstawia relacje z mieszkańcami Pieniążkowic, „którzy przywykli już do ofiar w swoim sąsiedztwie sprawowanych, w większości bardziej się oddali nałogowi palenia ziela nikotynowego" ${ }^{20}$. Łacińską część kroniki kończą krótkie wzmianki o dalszych planach i pracach proboszcza: o objęciu urzędu, o sprowadzeniu organów do kościoła, o wybudowaniu szkoły. Całość kończy zdawkowe zdanie: „Co dalej się działo, albo jakie wydarzenia, czy też wypadki miały miejsce, lata następne pokażą" ${ }^{21}$. Zważywszy na dokonania księdza Misia, o których napisałam wcześniej, należy uznać, że swej kroniki nie miał kiedy doprowadzić do końca, a pisząc ostatnie jej słowa, był zajęty innymi sprawami (zapewne śmiercią kolatora, działaniami powstańczymi, etc.).

Jak widać osoba, która spisała dziewiętnastowieczne dzieje kościoła pod wezwaniem św. Marii Magdaleny w Odrowążu, była daleka od osądzania, a nawet szczegółowego przedstawienia konfliktu między parafianami mieszkającymi w Odrowążu i Pieniążkowicach. Sądząc z opisu, który starałam się pokrótce przedstawić, skłócone strony po prostu odmawiały współpracy. Powściągliwy autor pominął milczeniem drażliwe elementy sporu, jak również fakt, że ciągnął się on przez wiele lat. W przedstawieniu swej osoby równie skromny, nie pozostawił właściwie żadnych pisemnych śladów ogromnej, wieloletniej pracy, którą poświęcił na rzecz swej parafii. Na szczęście dla nas pozostały trwałe jej ślady: zarówno w innych dokumentach, jak i w samym kościele w Odrowążu.

\section{Historia \\ Ecclesiae Parochialis in Odrowąż Per secundum ex ordine Parochorum 1844 conscripta.}

Pagus Odrowąż, in cuius medio haec Ecclesia stat, ad [unum] milliare semet extendit, constat ex 20 sic dictis Rolis, continet 200 domus, cum una Scultetia, quondam nobilis familiae Odrowążki, nunc autem familiae Bielański. Ad hanc Ecclesiam incorporati sunt praeter Odrowąż pagi: Pieniążkowice, Dział et Załuczne, spectantes olim ad Cameram Regiam in Dinastia Noeforensi usque 1819. Disvenditis universis bonis hic Cameraticis, in haereditatem Nobilis Sebastiani Stadnicki de Szreniawa venerunt cum aliis, quae nunc sub Domino Klikuszowiensis continentur. Hi 4 pagi ad Ecclesiam matricem in Czarny Dunajec spectabant - primo An. 1819 Decreto Supremiae Cancellariae Aulicae de 23 Aprilis, $\mathrm{Nr} 16175$, data facultate novam Ecclesiam erigendi, qua obtenta, 22 Julii 1825, in festo B. M. Magdalenae, quae fuit patrona Magnificae Dominae Czerny de Schwarcenberg,

\footnotetext{
${ }^{19}$ Solummodo nudi quatuor parietes.

${ }^{20}$ Qui pro divinis ad partes Arventes assueti, magis pro cremato, et tunc libere vendita herba nicociana majori ex parte viverunt?

${ }^{21}$ Quid ulterius factu, aut quales eventus vel cassus fuere, sequentes anni indicabunt.
} 
uxorisque Sebastiani Stadnicki de Szreniawa, in cuius Patronae gratiam, etiam Ecclesia obtinuit tutelarem eius Patronam.

Absolutis divinis in Capella Pieniążkowicensis, in praesentia multorum hospitum et concursu populi fundamenta Ecclesiae, hic in Odrowąż juxta ritum Romanae Eccles[iae] Cath[olicae] ad lapidem angularem, hora 3 pomeridiana, anno et die supradicto, imposita fuere, cujus benedictionis tenor apponitur:

\section{„Laudetur Jesus Christus. Amen}

Res humanae memoria labuntur quamprimum descriptio earundem cara posteritati $\mathrm{u}[\mathrm{t}]$ relinquuntur, propterea edocti ab Antecessoribus $\mathrm{p}$ [iae] $\mathrm{m}$ [emoeriae], viris prudentissimis, vobis o Carissimi posteri quae facta, in scriptio relinquimus, authentica de hoc tempore. - S[anctis]simus Papa Leo XII regit nunc Ecclesiam Rom[anam] Catholicam, qua Capit universae Ecclesiae. Augustissimus, invictissimus, pietissimus Franciscus II Imperator Austriae et Rex Galliciae et Lodomeriae. Sub eo sanctum foedus Augustissimi ec Serenissimi Reges et Imperatores videlicet Alexander I Russ, Vilhelmus III Pruss, Carolus X Catholicissimus, Ferdinandus VII, Angliae Georgius IV, Schvedes, Carolus et Minor Potentatum, qui propterea sanctum foedus iniere, ut libertas babyloniorum ad praesens Carbonariorum dictorum de terra tollat. Iam, infrascripti, super Domitor Europae relegatus, secundario Insulam Helenam vitam finiverat. Famosa illa pugna ad Lipsiam Saxonia, ubi populi Europae omnium Nationum (belluino modo) contra Gallos Imperatores pugnavere. At post tot praelia, magna victores foederati sub Augustissimo Imperante Catholico Deo Ipsi victrici Ter Optimogratiae in campo libero finito praelio redidere. Brevitatis causa omittimus caetera, ad Historiam relegamus.

Id Vobis, Carissimi posteri, notitia indubitata tradimus. Anno Salutis 1813 tantam inundationem aquarum in his oris mansisse, et in integro Regno Poloniarum, ut credentes universale Diluvium Philosophi coacti fuerunt dicere fuit diluvium. Quot milia hominum in ipso regno Galliciae, quot Ecclesiae et domus, populi etc. periere, quis describere poterit. Iam revertimur ad Ecclesiam neo Aedificandam parochialem, vi Decreti Augustissimi Imperatoris, Anni 1819 dies hodierna 22 Julii Anii subscripti est festiva S[anctae] Mariae Magdalenae, onomaticus Magnificae Dominae Czerny de Schwarzenberg - Szreniawa Stadnicka, cohaeredissae Collatricis, Conthoratis, et juxta mulierem fortem quis inveniet. Bona Mater, Rectrix Domus et sufficit Filia vera Conthoralis, Magnificus de Szreniawa Sebastianus Stadnicki ad perpetuam memoriam posteritati in bonis propriis haereditariis ab aerario Summo coemptis, habens ius ab Augustissimo Imperante supra capresso Nominis, Patronam pro Patrona Ecclesiae eligit, ac fieri cum Consensu quod sperat ac manebit, Illustris[simi] ac Reverendissimi Praesulis Gregorii Thomae Ziegler, Ep[iscopus] Dei gratias Tynczensis, neo erectae Diocensis, prius Tarnoviensis, prius adhuc Cracoviensis, Statium in Regnis Galliciae et Lodomeriae Praelati, demandatis, Praesentibus Decano foraneo Neoforensi, Praepositi ibidem, digno merito Ioanne Carolo Czekajski, Reverendissimo C[anonicorum] R[egularium] Scholarum Nationalium per Distrit Inspectore, V[ice] Decano Neoforensi ac Praeposito CzarnoDunajcensi, Curato ultimo iam quo ad Odrowąż, e statu Spirituali.

E statu Nobilium hic fuerunt praesentes: Magnificus ac Nobilis Alexander de Jastrzębiec Srokowski, Haerede successionali in Lipowa ad Sandeciam, Genero Magnificiorum Collatorum - magnifico ac Nobili filio Hilario de Szreniawa Stadnicki, ac Magnifico Domino Nobili Josepho de Szreniawa Stadnicki ex juvenili Clero, quam Civilib[us] congregatis adhunc Solemnem Ritum, non praetermittiae hic praesentia R[everendissimi] Francisci Leja Comitatus Arvensis, qui his Villis proposse supplendo Parochum Czar- 
no-Dunjacensem Sacramenta S[anctis]sima administraverat in necessitate, praesens hic Civilibus Dominus Mathaeus Rapacki quondam Proconsul Civittis Neoforensis, praesens haeres Ignatius Kustel, magister polium Neof[orensis] et haec e Schola prima in Districtu de An[nno] 1785 per Augustissimum p[iae] m[emoriae] Imperatorem Josephum II sistemisata.

Plura describere non valeo ab brevitatem temporis, o Carissimi posteri, sicasus quondam evenerit in saeculo et hanc Cartam descriptam inveneritis, perlecta ea fidete, nec minimum hoc doli Vobis scribimus, ut crucinatis cum historia temporibus, pro nobis Deum Omptem invocate, viventes successoribus ea relinquant.

Successores in manus recipiendo non Solummodo animae nostrae, ac cineribus nostris agitativis interra bene precate. Stabimus insimul in tremendo Iudicio Dei. Chartam praesentem ad lapidem angularem, juxta ritum S[anctae] Rom[anae] Eccl[esiae] imponendo ipso die, mense, anno infrascripto, hora tertia pomeridiana finimus, et nos finiemur.

Signat in Aede Plebanali in Odrowąż, nondum finita, die 22 Juli 1825:

$\mathrm{R}$ [everendissimi] D[omini]

Czekayski qua Parochus

Sebastianus Stadnicki

Ignatius Machayski

Alex Srokowski

Hilary Stadnicki

Joseph Stadnicki

Franciscus Leja

Eug[enius] Strakay

Math[ias] Rapacki

Joseph Knott

Andreas Sontagh

Thomas Bryniarski

Ioannes Komperda

Anton Pyzowski

Andrzej Bielański

Józer Bielański

Ze strony Urzędu grom[adzkiego]:

Maciej Dusza wójt

Jakób Dusza przysiężny

Maciej Głowacz

Franciszek Gal

Jędrzej Gal

Jakób Łasieński

Jędrzej Dusza

Maciej Dzielawa

Jakób Dusza

Nieumiejących pisać podpisał Pizon.

Facta benedictione Angularis lapidis, populus novae Parochiae hujus desiderio flangrans templum Dei in oris suis cernere, cum alacritate et diligentia ad hac opus manus apposuit. Ast simul cum magno squalore eorum, et pressione a Dominis terestribus, plane integrum pondus tam laborum, quam solutionis suis viribus levare coacti sunt. Et per decursum sex annorum struebatur namprimo 22 Augusti 1831 Ecclesia cum turi finita est. 
Anno sequenti, id est 1832, Altare maius totum ligneum construitum, collocatumq[ue] per Josephum Kułach rusticum de parochia Szflariensi ex villa Glejczarów sat apte, ad normam Neoforensis Altaris. In medio huius altaris est imago S[anctae] B[eatae] M[ariae] Magdalenae picta per celebrem pictorem D[ominum] Joan[em] Cant[ium] Wojnarowski Accademiae Cracoviensis, expensis Magn[ae] Dominae Magdalenae de Szreniawa Stadnicki et alia S[ncti] Sebastiani in summitate altaris praeter quas Imagines pictas nihil amplius in tota Ecclesia pictum extisit. Post Imaginem B[eatae] M[ariae] Magdalenae est figura Jesu [Chris]ti magnitudinis viri cum adstantibus aliis duabus S[anctae] Mariae, et $\mathrm{S}$ [ancti] Joannis veluci istae magnae inclusae ineptissime ex ligno scuptiae.

Tota structura Altaris consistit e duabus columnis quas capite levant duo Cherubin. In summitate columnae Septemtrionalis est figura S[ancti] Antonii, ad huius est S[ncti] Leonis papae - in vertice columnae meridionali est S[ancti] Josephi ad latus huius S[ancti] Hilarii Ep[iscopi]. Circa marginem Imaginem S[anctae] M[ariae] Magdalenae sunt parvae complurium Seraphim Sculptae facies, et duo parvi Cherubin - Infra Imaginem in medio altaris est tabernaculum pro asservando $\mathrm{S}[$ anctis]s[i]mo cum piade incomode et inepte constructum. Circa quot duo Cherubin flectentes, et superius duo candelabra tenentes. Penes Sacristiam est Ambona - quam cum Altari sicut Suprascriptum solus unice D[omini] Sebastiani Stadnicki haeres et collator solvit, et ad regiment huius Ecclesiae quaqua primus, primo Parocho Adalberto Kubacki praesentam dedit.

\section{Parochus [Primus]}

Primus Parochus hoc beneficium accepit M[agnificus] R[everendissimus] Adalbertus Kubacki, qua Parochus Czarnodunajcensis qui propter multus inamoenitates quas perpessus est tunc temporis sub malae notae Caitano Barone de Borowski, cujus historiam aquisitionis bonorum Czarny Dunajec, processus, vitae et factorum non est hic nostrum dicere, sed Chari Posteri ex ore universi populi in his oris Carpaticis post longam post nos seriem annorum traditam audituri obstuperient. Dolendum erit, si in Czarny Dunajec pro pereni memoria, monitione, cautione, et doctrina scriptis non reliquentur, esset dignis Posteris veluti apibus e venenatis floribus mel accipientibus. Hinc sub intelligent chari Posteri ab causam hic Parochus abolicando beneficio Czarny Dunajec, accepit Odrowąż. Obtenta itaq[ue] praesenta a praefato D. Sebas[tiano] Stadnicki Collatore die Februario 1832, qua Parochus in Odrowąż insitutus.

Sub ejus praesentia imprimis procurata est campanula Signatoria dicta per J[oannem] Bielański Scultetum - Pixis pro S[anctissimo] in tabernac[ulum] per Laurentium Bielański, et ejus consortem Appartementa 4 et duo calices attriti ex Capella Pieniążkovicensi accepta, Appartamenta 5 pro Solemnitate cum 3 campanullis ad Missam donavit. Ad M[agnificus] Andreas Duszeński, Parochus in Klecza, natus ex Odrowąż. Item Ecclesia haec sub Consecrata est per Reverendissimum ac Illust[rissimum] Praesulem Gran: de Paula Pisteli natione bochemo, Ep[isco]pum Tarnoviensem die prima Augusti 1832 Reliquiae S[anctorum] Martyrum Stanislai, Gregorii, et S. J. Cantii alteri Impositae Cujus Consecrationis Decretum sequentibus hic ad amusim pro perenni memori ponuntur verbis ut pote:

M.D.C.C.CXXXII Die prima Augusti Ego Franciscus de Paula Episcopus Tarnoviensis, Consecravi Ecclesiam Parochialem in Odrowąż in Honorem Sanctae Mariae Magdalenae, et Reliquias Sanctorum Martyrum Stanislai, Gregorii, et Joannis Cantii, in Altari inclusi, et singulis Christi fidelibus hodie unum annum, et in die anniversario consecrationis hujus modi ipsam visitatibus quadragenta dies de vera indulgentia in forma Ecclesiae consveta consecci (s[igillum] 1[oco]) Franciscus de Paula, Episcopus. 
Item sub hoc Parocho procuratae sunt duae Campanae per Communitates, seu parochianos, quae in turi pendent. Benedictae per Archipiscopum Olomucensem die et anno ut inferius de verbo ad verbum ponitur ut pote.

A Reverendissimo Celsitudine Domino Dno Maximiliano Iosepho e Liberis Baronibus de Somerau Beeckhr Archipiscopo Olomucensi, Duce, Principe, Regie Capellae Bohemiae Comite, decorato aurea cruce militari pro piis meritis et eo die inferius apposita.

Campanam hancce in honorem S[anctae] Magdalenae pro Ecclesia Odrowązensi i Dioecensi Tarnoviensi esse benedictam.

Nominis mei subscriptione, et Sigilli usualis impressione testor.

Olomueri die 27 mensis Martii 1838

(s[igillum] 1[oco]) Antonius Tiala $\mathrm{m}[\mathrm{anu}] \mathrm{p}$ [ropria]

Ceremon[iosus]

Secundae campanae benedictio rursum ut inferius. A Reverendissimo Celsitudine Domino Dno Maximiliano Iosepho e Liberis Baronibris de Somerau - Beeckhr Archipiscopo Bohomiae Comite, decorato aurea cruce militari pro piis meritis etc. die inferius apposita. Campanam hancce in honorem B[eatae] Virginis Mariae in usum Eccl[esiae] Parochiali Odrowązensis in Dioecesi Tarnoviensi esse benedictam. Nominis mei subscriptione, et Sigilli usualis impressione testor.

Olomun die 27 mensis Martii 1838

$\mathrm{s}$ [igillum] 1[oco]) Antonius Tiala m[anu] p[ropria]

Ceremon[iosus]

Sub ejus existentia hac notatu dignum, quod ejus solicitudine Stabula horea, celarium cum supra frumentario ex lapidibus constructum fuerit. Item quod ejus conatu additamentum ad congruam pro persona Parochi 205 floren[os] apud Excelsum Gubernium et Inventarium elaboratum sit. Quid, et quae plura facturus esset in placabilis Cleto filum vitae ejus seidendo febri delivit, nam usque 6 Februarii 1839 nervosa febri extinctus est et inadditu ex parte meridionali seu portim vulgo in babieniec sepultus.

Cui gratus Succesor scissis literis in lapide monumentum posuit: "Pierwszemu plebanowi Wojciechowi Kubackiemu na Odrowążu zmarłemu dnia 6 lutego R. P. 1839. ten pomnik postawił następca."

\section{Capella Pieniążkowicensis}

Ne oblivioni tradatur mentionata Capella Pieniążkovicensis, fors interogans quis ex Charis Posteris legendo in, exordia remoto post nam seculo haec verba Pinilis divinis in Capella Pieniążkovicensi etc. etc. aut audiendo de hac diversos sermones ex ore populi aetate mutatos, aut fictos, cupidus sciendi, quae esset illa Capella, aut in qua loco esset quae fors successu temporis sicut omnes res humanae labuntur nos quoque transimus, imperia potentissima et civitates evertuntur teste experientia, ubi est Potentia Babilonis, Assyriorum, Graecorum, Romanorum, etc. - ubi Troja Babilonis, Jeruzalem etc. Et haec Capella, quae jam ad ruinam vergit, non habens patronum neque benefactorem, cujus locus tantum monstrabitur, et nihil certi aut scire posset. Breviter ergo hic describitur ut pote.

Quam primum notum factum est Decretum Aulicem de dismembratione Ecclesiae Czarno-Dunajec, et separatione harum 4 villarum - Odrowąż, Pieniążkowice, Dział et 
Załuczne at quod in illis Ec[clesiis] Parochi sit futura, illico sunt discordiae exortae de loco ubi erigenda esset. Itaque scisso facta in duas partes Odrowąż cum Załuczne, ut in Odrowąż - Pieniążkowice et Dział, ut in Scultetia Pieniążkovicensi sit. Odrowązenses emerunt 6 partem agri dictae Rolae Czarny z Grządzielem et aedificarunt domum parochialem in loco in quo nunc stat, ligneam quae sub benedictione necdum finita fuit. Ex altera parte Pieniążkovicenses aedificarunt parvam ex asseribus Ecclesiunculam, et profecti ad civitatem vetero Sandecium ubi cassatum tunc temporis erat Franciscanorum monasterium et conduxerunt sed hucdum non solverunt, ex aliquo illius monasterii unum maius et secundum minus altare cum omnibus requisitus, et antiqua 4 appartamenta et locarunt in sua Ecclesiuncula, et benedicta per parochum Czarno-Dunajcensem ubi divina absolvebantur, ex Dunajec excurendo donec processus fiebat et donec in Odrowąż Ecclesia non extitit, imo et coemeterium circa hanc Ecclesiunculam Pieniążkovicensem sepibus monitum erat, in quo sepeliebantur. Per integrum tempus ab obtenta facultate, supradicta a Suprema Cancellaria aulica 23 Julii 1825 maximi erant processus, invidiae, discordiae, inter has partes, et plane cum maximo damno illorum expensarium sub Cameralio judicio - non semel, his non semel illis promettebatur - Pieniążkovicenses maximam spem habebant. Siquidem certus Joseph Waligórski scultetus suam Scultetiam qua coclebs haeres promittebat praesertim qui accepit ab R[everendo] Flor[iano] Knais parocho Dunajcensi, pecuniam pro erigenda et fundanda Ecclesia (quod ejus etiam hic in actis copia testamenti testatur, qui mortuis in Raba Wyżna - proficiscens versus Cracoviam. Ast et hic Joseph Waligórski paulo post mortuus reliquit dispositionem suae sororis marito Zientarski, qui semper spondebat, ast fine finali Scultetiam denegavit, et hinc spei factus finis. Hic victores processus Odrowązenses evasere (Acta hujus processus hucdum extant in Biblioteca parochiali cum Copia Floriani Knais). Hic vice versa Pieniążkovicenses spe elusa animo consternati usque ad ultimum tempus omnes animo suspensi et si ex Successu in Ecclesia Czarno-Dunajcensi promulgatum fuisset, futuram celebrationem divinorum in Capella Pieniążkovicensi fine Imponendi, et benedicendi lapidis Angularis in festo S[anctae] $\mathrm{M}$ [ariae] Magdalenae as necdum quo in loco erit, significatum, primo congregatu popula ad Odrowąż demonstratur. Ab hoc tempore Summa invidia, et discordiae inter has litigantes partes enate, quae tante fuerunt ut nisi vi coacti nec laborare nec contribuere volubre, et huc usque hoc odio, jam remotis spirunt et dolent, imo aedificata jam Ecclesia in qua divina peragebantur nec adire eam voluerunt.

Fidendo egre mentionatus Parochus has discordias, objurgationes et odia Pieniążkovicensium et vilipensionem Ecclesi[ae] Odrowąż, qui nec frequentare ad divina voluere, appartamenta calices, verba omnia qua procelebratione misa sunt ex Ecclesia Pieniążkowice accepit, et divina ibidem celebrare denegavit, sepultum omnium penes Ecclesi Odrowąż mandavit - remanserunt ibidem Altaria majus pulchre Structurae deaurationis, et picturae in qua antiqua imago S[anctae] Mariae Dolorum, et alterius Altaris optimae sculpturae et deaurationis in quo celebris pictoris S[ancti] Bonaventura[e] Imago cernitur quae hucdum stant dolendum per in Incuriam in ruinam ferient, et ad parietem picta Imago $\mathrm{S}$ [ancti] Francisci in ramis pendens et in turri campanula pulchri sonitus - tanta demontia et coecitas mentis vellent praeter lapsa habere et enores suos notunt corrigere - amant locum illum, dolent, ast nec miniti reparant.

\section{Parochus Secundus} Annus Domini 1839

Joannes Cantius Miś, natus in Zembrzyce, Circuli Wadowicensis, 24 Octobris 1807, Gymnasium integre absolvit Podolini, Philospohiam Rożnowice in Hungaria, Studia vero 
Teologica Leopoli - Ordinatus per Archi Ep[iscopum] Ankiewicz de Skarbek 1833 primo applicatus ad Ecclesiam in Czarny Dunajec, qua Cooperator, deinde ad Eccl[esiam] in Klikuszowa, qua Expertus. Unde ad hanc promotus, pro qua institutus 2 Augusti 1839 et instalatus 11 eiusdem Mensis. Obtento autem hoc beneficio, obtinuit etiam et campum, ad laborandum, et expensas.

Quoniam nihil tam, in Ecclesia, quam circa eam erat, solummodo nudi quatuor parietes, excepto Altare majori, ex ligno non picto Ambona et Baptisterio.

Causa consequens quia noviter aedificata non acta annos numerabat, a finitione, quoniam 1831 totaliter finita, quae sex annis aedificabatur. Domus parochialis, quoque perdimidium putrefacta quia longo tempore, de ligno exstructa, absque tegumento stabat, et hocpropter processum inter Odrowąsenses et Pieniążkovicenses - Odrowąsensen emerunt 6 partem agri Rola Czarny z Grządzielem dicti, in qua hanc domum aedificarunt. Pieniążkovicenses vero emerunt Altaria ex capsato tunc Monasterio Vetero Sandecii, et ex ligno Ecclesiunculam aedificaverunt - inqua celebrabatur S[anctae] Missae, et penes sepeliebantur longo tempore donec palmam victoriae eis Odrowąsenses eripuerunt.

Talem Ecclesiam, talem parochiam primus Parochus qui non plene 6 annis hic vixit successori Secundo reliquit. Et quid dicendam de parochianis neglectis? qui pro divinis ad partes Arventes assueti, magis pro cremato, et tunc libere vendita herba nicociana majori ex parte iverunt?

Obstupuit praesens Parochus, moeroque consternatus, videns tantam miseriam, tantum defectum, tantam necessitudinem, et in morali et in phisico statu sed collocata firma spe in Omnipotenti Deo forti animo spopondit, firma, et non ficta voluntate anteposuit, eamque non quiescere donec omnia ad effectum tam in Ecclesia, quam in Parochia, quam circa eam que maxime necessaria tunc deducat; quod et effectu: (ut tardius videbitur) comprobavit.

Nam Organum antiquum ex Szaflary 90 fl[orenos] emit, et collocavit per Ludimagistros correxit, et primam Missam his celebrans cum lusu organorum absolvit.

Facta Instalatione Solemni, pro qua Multi Sacerdotes amici, et cognati convenerunt. Illico de rebus maxime necessariis conatum revertit. Imprimis videns nullam in parochia Scholam, etsi nomine fuit, sed non re quia rustici conducta domo $10 \mathrm{fl}$ [orenos] in annue per parochianos soluta, in quo cubili simul habitavit Ludimagister nomine Vincentius Chlebowski. Quare parochus omnem conatum adhibuit, et Colatorem D. tunc viventem Hilarium Stanicki de Szreniawa rogavit et comovit, ut materialia praeparaverat, quot et praeparaverit, et in futuro Anno aedificaverit.

Ceterum autumnale tempus, ad praeparandas, et in ordinem deducendo portas convertit, et sic feliciter annum hunc Deo cum laude finivit. Quid ulterius factu, aut quales eventus vel cassus fuere, sequentes anni indicabunt. 


\title{
THE HISTORY OF THE PARISH IN ODROWĄŻ PODHALAŃSKI IN THE LIGHT OF THE PARISH CHRONICLE
}

\begin{abstract}
Summary
The reader is presented with an article based on the chronicle of the parish in Odrowąz, which originated in 1819 and describes its history till the end of the 19th century. The author of the text was Jan Kanty Miś - the first official rector of this parish. He shortly described its history as well as that of the church. He also listed the furnishings of the temple and characterized its mural paintings. The text, written in Latin, also contains biographies of the first two rectors of the parish.

At the turn of the nineteenth century many churches affiliated to existing parishes in the southern part of Poland became independent. The first community to have undergone this process was that of Chochołów and later on similar efforts were made by inhabitants of Pieniążkowice. In 1818 the construction of the church started. According to regulations, each new parish should consist of at least one thousand worshippers. At the same time villagers from Odrowąz, which was only 1.5 $\mathrm{km}$ away from Pianiążkowice, also commenced the construction of their own temple. In 1819 the decision was made by the authorities to found the new parish in Odrowąż with the villages of Dział, Pieniążkowice and Załuczne becoming its part. In the next years the two constructions were carried on simulataneously, namely the legal one in Odrowąż and the illegal one in Pieniążkowice. The argument between the two communities continued despite intervention of state authorities, the owners of the villages as well as the rector.
\end{abstract}

Translated by Justyna Lukaszewska-Haberkowa 